\title{
The stimulatory effect of the octadecaneuropeptide ODN on astroglial antioxidant enzyme systems is mediated through a GPCR
}

\author{
Yosra Hamdi ${ }^{1}$, Hadhemi Kaddour ${ }^{1}$, David Vaudry ${ }^{2,3,4}$, Salma Douiri ${ }^{1}$, Seyma Bahdoudi ${ }^{1}$, \\ Jérôme Leprince ${ }^{2,3,4}$, Hélène Castel ${ }^{2,4}$, Hubert Vaudry ${ }^{2,3,4}{ }^{*}$, Mohamed Amri ${ }^{1}$ *, \\ Marie-Christine Tonon ${ }^{2,4}$ and Olfa Masmoudi-Kouki ${ }^{1}$
}

\author{
Laboratory of Functional Neurophysiology and Pathology, Research Unit UR/11ES09, Department of Biological Sciences, Faculty of Science of Tunis, \\ University Tunis El Manar, Tunis, Tunisia \\ ${ }^{2}$ Inserm U982, Laboratory of Neuronal and Neuroendocrine Communication and Differentiation, University of Rouen, Mont-Saint-Aignan, France \\ ${ }^{3}$ International Associated Laboratory Samuel de Champlain, Mont-Saint-Aignan, France \\ ${ }^{4}$ Regional Platform for Cell Imaging of Haute-Normandie, Institute for Medical Research and Innovation, University of Rouen, Mont-Saint-Aignan, France
}

\author{
Edited by: \\ Jae Young Seong, Korea University, \\ South Korea

\section{Reviewed by:} \\ María M. Malagón, University of \\ Cordoba, Spain \\ Kouhei Matsuda, University of \\ Toyama, Japan

\section{${ }^{*}$ Correspondence:} \\ Mohamed Amri, Laboratory of \\ Functional Neurophysiology and \\ Pathology, Research Unit UR/11ESO9, \\ Department of Biological Sciences, \\ Faculty of Science of Tunis, University \\ Tunis El Manar, 2092 Tunis, Tunisia. \\ e-mail:mohamed.amri@fst.rnu.tn; \\ Hubert Vaudry, Inserm U982, \\ Laboratory of Neuronal and \\ Neuroendocrine Communication and \\ Differentiation, International \\ Associated Laboratory Samuel de \\ Champlain, Regional Platform for Cell \\ Imaging of Haute-Normandie, \\ Institute for Medical Research and \\ Innovation, University of Rouen, \\ 76821 Mont-Saint-Aignan, France. \\ e-mail: hubert.vaudry@univ-rouen.fr
}

Astroglial cells possess an array of cellular defense systems, including superoxide dismutase (SOD) and catalase antioxidant enzymes, to prevent damage caused by oxidative stress on the central nervous system. Astrocytes specifically synthesize and release endozepines, a family of regulatory peptides including the octadecaneuropeptide (ODN). ODN is the ligand of both central-type benzodiazepine receptors (CBR), and an adenylyl cyclase- and phospholipase C-coupled receptor. We have recently shown that ODN is a potent protective agent that prevents hydrogen peroxide $\left(\mathrm{H}_{2} \mathrm{O}_{2}\right)$-induced inhibition of SOD and catalase activities and stimulation of cell apoptosis in astrocytes. The purpose of the present study was to investigate the type of receptor involved in ODN-induced inhibition of SOD and catalase in cultured rat astrocytes. We found that ODN induced a rapid stimulation of SOD and catalase gene transcription in a concentration-dependent manner. In addition, $0.1 \mathrm{nM}$ ODN blocked $\mathrm{H}_{2} \mathrm{O}_{2}$-evoked reduction of both mRNA levels and activities of SOD and catalase. Furthermore, the inhibitory actions of ODN on the deleterious effects of $\mathrm{H}_{2} \mathrm{O}_{2}$ on SOD and catalase were abrogated by the metabotropic ODN receptor antagonist cyclo $_{1-8}\left[\mathrm{Dleu}^{5}\right] \mathrm{OP}$, but not by the CBR antagonist flumazenil. Finally, the protective action of ODN against $\mathrm{H}_{2} \mathrm{O}_{2}$-evoked inhibition of endogenous antioxidant systems in astrocytes was protein kinase $\mathrm{A}$ (PKA)-dependent, but protein kinase $\mathrm{C}$-independent. Taken together, these data demonstrate for the first time that ODN, acting through its metabotropic receptor coupled to the PKA pathway, prevents oxidative stress-induced alteration of antioxidant enzyme expression and activities. The peptide ODN is thus a potential candidate for the development of specific agonists that would selectively mimic its protective activity.

Keywords: astrocyte, catalase, ODN, ODN metabotropic receptor, oxidative stress, SOD, protein kinase $A$

\section{INTRODUCTION}

The octadecaneuropeptide (ODN) is a peptide generated through the proteolytic cleavage of the 86-amino acid precursor diazepambinding inhibitor (DBI; Guidotti et al., 1983) which is exclusively expressed in astroglial cells in the central nervous system (CNS) of mammals (Malagon et al., 1993; Burgi et al., 1999; Tonon et al., 2006). DBI and its derived peptides are collectively designated by the term endozepines (Tonon et al., 2006). It was initially reported that ODN acts as an inverse agonist of central-type benzodiazepine receptors (CBR) that are intrinsic components of the $\mathrm{GABA}_{\mathrm{A}}$ receptor-chloride channel complex (Ferrero et al.,

Abbreviations: AC, adenylyl cyclase; CBR, central-type benzodiazepine receptors; CREB, cAMP-responsive element-binding protein; DBI, diazepam-binding inhibitor; GADPH, glyceraldehyde-3-phosphate dehydrogenase; $\mathrm{H}_{2} \mathrm{O}_{2}$, hydrogen peroxide; ODN, octadecaneuropeptide; PBS, phosphate buffered saline; PKA, protein kinase A; PKC, protein kinase C; PLC, phospholipase C; ROS, reactive oxygen species; SOD, superoxide dismutase.
1986). It has been subsequently shown that ODN can also activate a $\mathrm{G}_{\mathrm{i} / 0}$ protein-coupled receptor leading to the activation of phospholipase C (PLC) in astrocytes (Patte et al., 1995; Leprince et al., 2001). In addition, recent data indicate that the ODN G protein-coupled receptor can also activate adenylyl cyclase (AC; Hamdi et al., 2012). ODN exerts a wide range of biological activities which are mediated either through CBR, i.e., increase of aggressiveness and anxiety (Kavaliers and Hirst, 1986; De MateosVerchere et al., 1998), reduction of pentobarbital-induced sleeping time and drinking (Dong et al., 1999; Manabe et al., 2001), or through a metabotropic receptor, i.e., inhibition of food intake (Do Rego et al., 2007). Similarly, at the cellular level, the diverse effects of ODN are mediated either through CBR, i.e., stimulation of glial cell and neuroblast proliferation (Gandolfo et al., 1999; Alfonso et al., 2012) and activation of neurosteroid biosynthesis (Do Rego et al., 2001), or through a metabotropic receptor, i.e., increase of intracellular calcium concentration in astrocytes 
(Leprince et al., 2001) and modulation of neuropeptide expression in neurons (Compère et al., 2003, 2004).

Oxidative stress, resulting from excessive production of reactive oxygen species (ROS), such as hydrogen peroxide $\left(\mathrm{H}_{2} \mathrm{O}_{2}\right)$, is implicated in the pathology of several neurological disorders including cerebral ischemia and neurodegenerative diseases (Garcia et al., 2012; Hayashi et al., 2012). An excess of $\mathrm{H}_{2} \mathrm{O}_{2}$ induces imbalance in ROS generation, impairs cellular antioxidant defences and finally triggers cell death by apoptosis (Emerit et al., 2004; Shibata and Kobayashi, 2008). It is well known that astroglial cells contain high levels of ROS scavenger molecules such as glutathione (Dringen etal., 1999) and the antioxidant enzymes Mn- and $\mathrm{Cu}, \mathrm{Zn}$-superoxide dismutases ( $\mathrm{Mn}$ - and $\mathrm{Cu}, \mathrm{Zn}-\mathrm{SOD}$ ), catalase and glutathione peroxidase (Lindenau et al., 2000; Sokolova et al., 2001; Saha and Pahan, 2007). Nonetheless, astroglial cells can be affected, in terms of viability and functionality, by an insurmountable oxidative stress (Ferrero-Gutierrez et al., 2008; Park et al., 2009). In particular, it has been shown that inhibition of SOD and/or catalase activities in cultured astrocytes is associated with an exacerbation of oxidative damages induced by $\mathrm{H}_{2} \mathrm{O}_{2}$ or hypoxia (Desagher et al., 1996; Bi et al., 2008; Li et al., 2008). Reciprocally, cultured astrocytes derived from $\mathrm{Cu}, \mathrm{Zn}$-SOD-overexpressing transgenic mice exhibit increased resistance to oxidative stress (Chen et al., 2001; Wang et al., 2005). However, little is known regarding the endogenous factors that modulate glial antioxidant systems. In this context, we have previously reported that, in cultured astrocytes, ODN exerts a potent protective effect against oxidative stress-induced apoptosis, and attenuates $\mathrm{H}_{2} \mathrm{O}_{2}$ evoked inhibition of SOD and catalase activities (Hamdi et al., 2011). More recently, we have shown that the anti-apoptotic activity of ODN is mediated through the metabotropic endozepine receptor (Hamdi et al., 2012). In contrast, regarding the effects of ODN on endogenous antioxidant systems, the receptor and the signaling mechanism are currently unknown. The purpose of the present study was thus to examine the effects of ODN on SOD and catalase gene expression and to determine the type of receptor involved in the antioxidant action of ODN on astroglial cells.

\section{MATERIALS AND METHODS \\ ANIMALS}

All experiments were performed in accordance with American Veterinary Medical Association. Approval for these experiments was obtained from the Medical Ethical Committee for the Care and Use of Laboratory Animals of Pasteur Institute of Tunis (approval number: FST/LNFP/Pro 152012).

\section{REAGENTS}

Dulbecco's modified Eagle's medium (DMEM), F12 culture medium, $\mathrm{D}(+)$-glucose, L-glutamine, $\mathrm{N}$-2-hydroxyethylpiperazine$N$-2-ethane sulfonic acid (HEPES), fetal bovine serum (FBS), the antibiotic-antimycotic solution, and trypsin-EDTA were obtained from Gibco (Invitrogen, Grand Island NY, USA). Bovine liver catalase, chelerythrine, DL-epinephrine, H89, Triton X-100, and insulin were purchased from Sigma Aldrich (St. Louis, MO, USA). Flumazenil was a generous gift from Hoffmann-La Roche (Basel,
Switzerland). Rat ODN and the G protein-coupled receptor antagonist cyclo $_{1-8}\left[\mathrm{DLeu}^{5}\right]$ OP were synthesized by using the standard Fmoc procedure, as previously described (Leprince et al., 2001). All other reagents were of A grade purity.

\section{SECONDARY CULTURES OF RAT CORTICAL ASTROCYTES}

Secondary cultures of rat cortical astrocytes were prepared as previously described (Castel et al., 2006). Briefly, cerebral hemispheres from newborn Wistar rats were collected in DMEM/F12 $(2: 1 ; \mathrm{v} / \mathrm{v})$ culture medium supplemented with $2 \mathrm{mM}$ glutamine, $1 \%$ insulin, $5 \mathrm{mM}$ HEPES, $0.4 \%$ glucose, and $1 \%$ of the antibiotic-antimycotic solution. Dissociated cells were resuspended in culture medium supplemented with $10 \%$ FBS, plated in $175-\mathrm{cm}^{2}$ flasks (Greiner Bio-one $\mathrm{GmbH}$, Frickenhausen, Germany), and incubated at $37^{\circ} \mathrm{C}$ in a $5 \% \mathrm{CO}_{2} / 95 \% \mathrm{O}_{2}$ atmosphere. When cultures were confluent, astrocytes were isolated by shaking overnight the flasks with an orbital agitator and plated on 35-mm Petri dishes at a density of $0.3 \times 10^{6}$ cells $/ \mathrm{ml}$. All experiments were performed on 5 - to 7-day-old secondary cultures.

\section{QUANTITATIVE RT-PCR ANALYSIS}

Cultured cells were incubated at $37^{\circ} \mathrm{C}$ with fresh serum-free medium. At the end of the incubation, the culture medium was removed and the cells were washed twice with phosphate buffered saline (PBS; 0.1 M, pH 7.4). Total RNA was extracted by using Tri reagent (Sigma, St Quentin Fallavier, France) and purified using the NucleoSpin kit (Macherey-Nagel, Hoerd, France). cDNA was synthetized from 3-4 $\mu \mathrm{g}$ of total RNA with ImProm II Promega kit (Promega). Quantitative RT-PCR was performed on cDNA in the presence of a $1 \times$ Fast SYBR Green universal PCR Master mix (Applied Biosystems, Courtaboeuf, France) containing concentrations of dNTPs, $\mathrm{MgCl}_{2}$, SYBR green reporter dye, AmpliTaq Gold DNA polymerase, and forward (5'-CCTTCTTGTTCTGCAACCTGCTA- $3^{\prime}$ ) and reverse (5'-CCGGACTCTCCGGTATCTGA- $3^{\prime}$ ) SOD (GenBank accession no. NM_012880) primers, or forward (5'-CCACAGTCGCTGGAGAGTCA-3') and reverse (5'-GTTTCCCACAAGGTCCCAGTT-3') catalase (GenBank accession no. NM_012520) primers, or forward (5'-CAGCCTCGTCTCATAGACAAGATG-3') and reverse (5' - CAATGTCCACTTTGTCACAAGAGAA-3') glyceraldehyde-3-phosphate dehydrogenase (GADPH, GenBank accession no. NM_017008) primers (300 nM, each; Proligo, Paris, France), using the ABI Prism 7000 sequence detection system (Applied Biosystems). The amount of SOD and catalase cDNA in each sample was calculated by the comparative threshold cycle $(\mathrm{Ct})$ method and expressed as $2^{-\Delta \Delta \mathrm{Ct}}$ using GADPH as an internal control.

\section{MEASUREMENT OF ANTIOXIDANT ENZYME ACTIVITIES}

Cultured cells were incubated at $37^{\circ} \mathrm{C}$ with fresh serum-free medium. At the end of the incubation, cells were washed twice with PBS and total cellular proteins were extracted by using the lysis buffer containing $50 \mathrm{mM}$ Tris- $\mathrm{HCl}$ (pH 8.0), 10 mM EDTA, $100 \mu \mathrm{M}$ phenylmethylsulfonyl fluoride, and $1 \%$ Triton $\mathrm{X}-100$. The homogenate was centrifuged $\left(16,000 \mathrm{~g}, 4^{\circ} \mathrm{C}, 20 \mathrm{~min}\right)$ and the cellular extract contained in the supernatant was stored at $-20^{\circ} \mathrm{C}$ until enzyme activity determinations. 
The activity of SOD was measured using a spectrophotometric assay, which consists in measuring epinephrine autoxidation induced by superoxide anion. Samples, prepared as described above, were incubated for 3 min with a mixture containing bovine catalase $(0.4 \mathrm{U} / \mu \mathrm{l})$, DL-epinephrine $(5 \mathrm{mg} / \mathrm{ml})$, and $\mathrm{Na}_{2} \mathrm{CO}_{3} / \mathrm{NaHCO}_{3}$ buffer $(62.5 \mathrm{mM}, \mathrm{pH} 10.2)$. The oxidation of epinephrine was measured at $480 \mathrm{~nm}$ with a BioRad spectrophotometer (Bio-Rad Laboratories, Philadelphia, PA, USA).

The activity of catalase was determined on the basis of the decrease of $\mathrm{H}_{2} \mathrm{O}_{2}$. Samples, prepared as described above, were mixed with $30 \mathrm{mM} \mathrm{H}_{2} \mathrm{O}_{2}$ in PBS. The disappearance of $\mathrm{H}_{2} \mathrm{O}_{2}$ was measured at $240 \mathrm{~nm}$ for $180 \mathrm{~s}$ at $30 \mathrm{~s}$ intervals. Catalase activity was calculated using the extinction coefficient of $40 / \mathrm{mM} / \mathrm{cm}$ for $\mathrm{H}_{2} \mathrm{O}_{2}$.

\section{STATISTICAL ANALYSIS}

Data are presented as the mean \pm SEM from three independent experiments performed in quadruplicate. Statistical analysis of the data was performed by using Student's $t$-test, ANOVA, followed by Bonferroni's test, and two-way ANOVA test. A p-value of 0.05 or less was considered as statistically significant.

\section{RESULTS}

\section{ODN INCREASES SOD AND CATALASE MRNA LEVELS IN CULTURED ASTROCYTES}

We have previously shown that picomolar concentrations of ODN suppress the inhibitory effects of $300 \mu \mathrm{M} \mathrm{H}_{2} \mathrm{O}_{2}$ on SOD and catalase activities in cultured rat astrocytes (Hamdi et al., 2011). To explore the mechanism involved in the effect of ODN on antioxidant enzyme systems we monitored SOD and catalase gene expression by quantitative PCR. Time-course experiments revealed that $\mathrm{ODN}(0.1 \mathrm{nM})$ significantly enhanced SOD and catalase mRNA levels within $2 \mathrm{~min}$ with a maximum effect after $10 \mathrm{~min}$ and $5 \mathrm{~min}$ of incubation, respectively (Figure 1A). Thereafter, the stimulatory effect of ODN on SOD and catalase expression gradually declined and vanished 60 and $30 \mathrm{~min}$ after the onset of ODN administration, respectively. Exposure of astrocytes to increasing concentrations of ODN (0.01 pM to $0.1 \mathrm{nM})$ induced a concentration-dependent increase of SOD and catalase mRNA levels (Figure 1A, inset). In contrast, incubation of astrocytes with graded concentrations of $\mathrm{H}_{2} \mathrm{O}_{2}(100-500 \mu \mathrm{M})$ dose-dependently decreased both SOD and catalase mRNA levels (Figure 1B). We next examined the effects of $\mathrm{ODN} / \mathrm{H}_{2} \mathrm{O}_{2}$ co-incubation on enzyme expression. For moderate concentrations of $\mathrm{H}_{2} \mathrm{O}_{2}(100-300 \mu \mathrm{M}), \mathrm{ODN}(0.1 \mathrm{nM})$ restored SOD and catalase mRNA levels above control, whereas for higher concentrations of $\mathrm{H}_{2} \mathrm{O}_{2}(400$ and $500 \mu \mathrm{M})$, ODN only partially prevented the decrease of SOD and catalase gene expression (Figure 1B).

\section{ODN BLOCKS $\mathrm{H}_{2} \mathrm{O}_{2}$-EVOKED INHIBITION OF SOD AND CATALASE mRNA LEVELS AND ACTIVITIES THROUGH ACTIVATION OF A METABOTROPIC RECEPTOR COUPLED TO THE PKA PATHWAY}

We next examined the type of receptor of ODN involved in the stimulatory effects of ODN on endogenous antioxidant systems. Administration of the selective metabotropic receptor antagonist cyclo $_{1-8}\left[\mathrm{DLeu}^{5}\right] \mathrm{OP}(1 \mu \mathrm{M})$ to cultured astrocytes did not induce any modification of SOD and catalase mRNA levels and activities, but totally abolished the effects of $0.1 \mathrm{nM}$ ODN on $\mathrm{H}_{2} \mathrm{O}_{2}$-evoked inhibition of antioxidant enzyme gene transcription and activities. In contrast, the CBR antagonist flumazenil $(1 \mu \mathrm{M})$ did not affect the protective action of ODN against the deleterious effect of $\mathrm{H}_{2} \mathrm{O}_{2}$ on endogenous antioxidant systems (Figures 2A,B).

Incubation of astrocytes with the selective protein kinase $\mathrm{A}$ (PKA) inhibitor H89 $(20 \mu \mathrm{M})$ abrogated the effect of ODN on the inhibitory action of $\mathrm{H}_{2} \mathrm{O}_{2}$ on SOD and catalase mRNA levels and activities. In contrast, administration of the protein kinase $\mathrm{C}$ (PKC) inhibitor chelerythrine $(0.1 \mu \mathrm{M})$ did not modify the effects of ODN (Figures 3A,B), indicating that only the PKA pathway is involved in the protective activity of ODN.

\section{DISCUSSION}

Alteration of endogenous antioxidant systems, especially decrease of SOD and catalase activities, causes exacerbation of oxidative damages leading to apoptosis in various cell types, including astroglial cells (Giffard and Swanson, 2005; Lopez et al., 2007; Bi et al., 2008). Here, we demonstrate that ODN prevents the decrease of SOD and catalase mRNA levels and activities induced by $\mathrm{H}_{2} \mathrm{O}_{2}$ in cultured astrocytes, through activation of a metabotropic receptor positively coupled to the AC/PKA signaling pathway.

We have previously reported that, in cultured astrocytes, ODN at very low concentrations (in the picomolar range) stimulates SOD and catalase activities (Hamdi et al., 2011). The present study shows that, in the same range of concentrations, ODN induces a dose-dependent increase of SOD and catalase mRNA levels in cultured astroglial cells, indicating that ODN regulates not only enzyme activity but also gene transcription. Although SOD and catalase genes exhibit hallmarks of typical housekeeping genes, it has been shown that their promoters encompass consensus sequences for regulatory elements such as metal-responsive element, antioxidant responsive element, glucocorticoid-response element, and nuclear factor-кB (Nenoi et al., 2001; Zhu et al., 2001; Zelko et al., 2002), suggesting that these genes are actually regulated in the CNS. As a matter of fact, SOD and catalase gene expression is selectively increased by inflammatory mediators such as interleukin- $1 \beta$, interferon (IFN) $-\gamma$, IFN- $\beta$, or lipopolysaccharides in astrocytes (Mokuno et al., 1994; Kifle et al., 1996; Vergara et al., 2010). Previous data have shown that ODN is specifically produced by astroglial cells (Tonon et al., 1990; Malagon etal., 1993; Compère etal., 2010) and that its release is regulated by various factors including agonists of formyl peptide receptors (Tokay et al., 2008) which are involved in inflammation. These observations suggest that ODN may act as an autocrine factor to finely regulate SOD and catalase gene expression in the brain.

Kinetic experiments indicate that the action of ODN on antioxidant enzyme gene transcription is very rapid but transient. Nevertheless, ODN exerts a protective effect against $\mathrm{H}_{2} \mathrm{O}_{2}$-reduced SOD and catalase mRNA levels. Similar time-response curves have already been observed on SOD and catalase activities, in cultured astrocytes (Hamdi et al., 2011). These data suggest that 
A

SOD

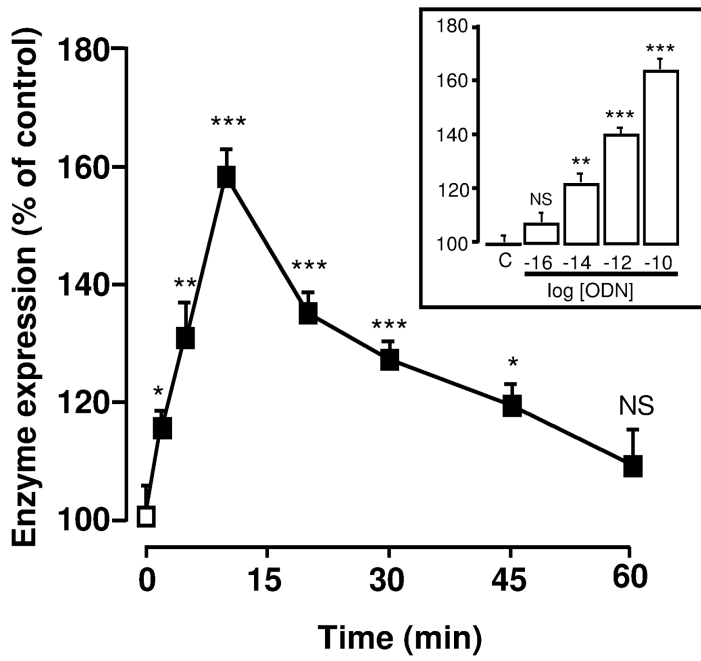

B $S O D$ $r \# H_{1} \quad r^{\# \# H_{1}} \quad r^{n S_{1}} \quad r s_{1}$

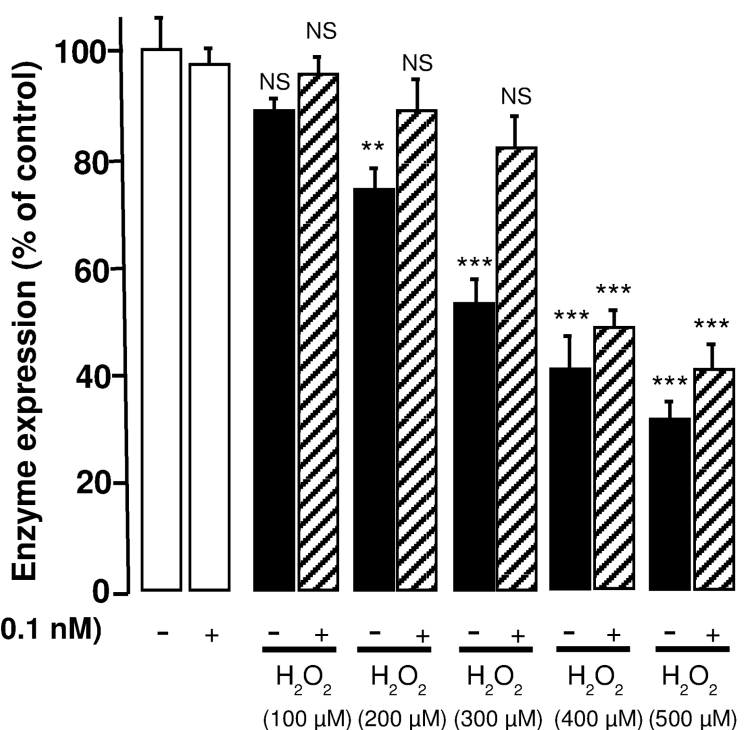

Catalase

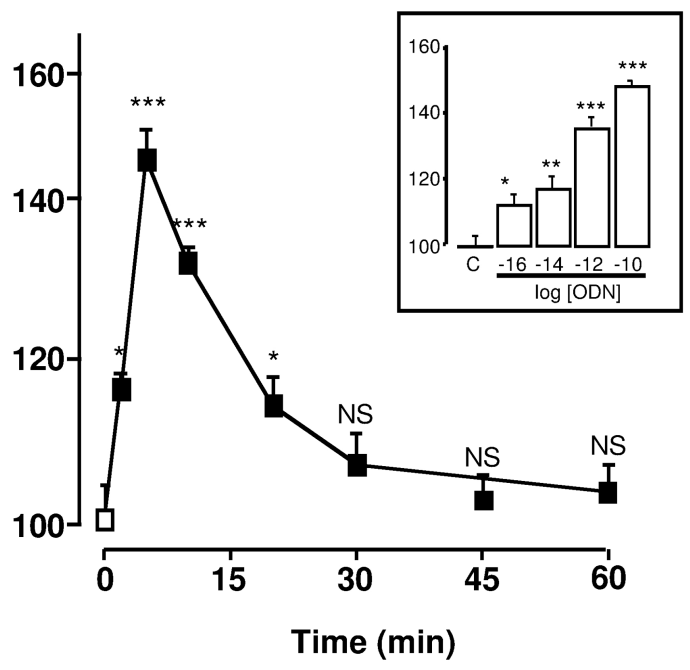

Catalase

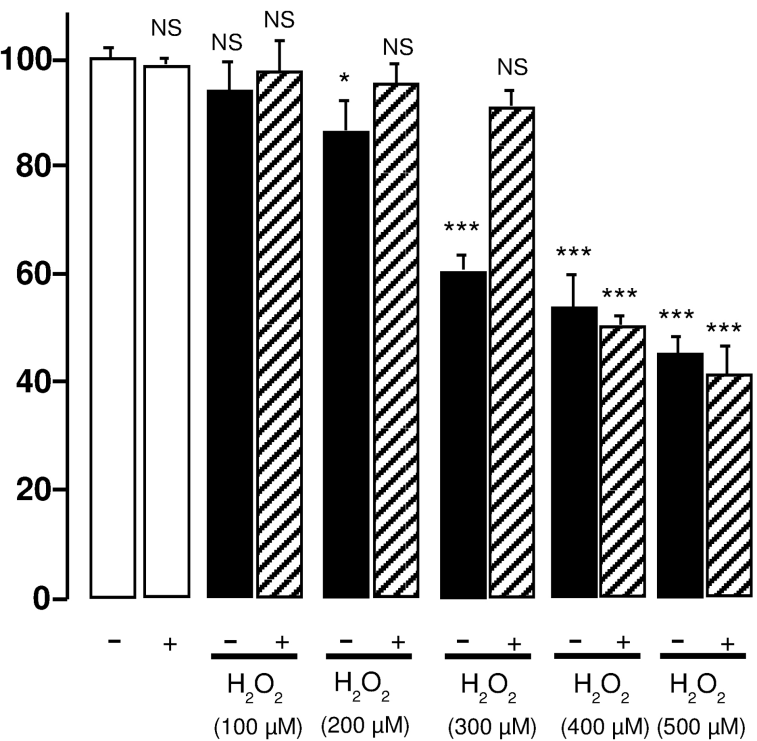

FIGURE 1 | Protective effects of ODN against $\mathrm{H}_{2} \mathrm{O}_{2}$-evoked inhibition of SOD and catalase mRNA levels in cultured rat astrocytes. (A) Effects of ODN on SOD and catalase mRNA levels. Astrocytes were incubated in the absence or presence of ODN $(0.1 \mathrm{nM})$ for the times indicated. Inset, cells were treated for $10 \mathrm{~min}$ with increasing concentrations of ODN $(0.01 \mathrm{pM}$ to $0.1 \mathrm{nM}$ ). SOD and catalase mRNA levels were measured by quantitative RT-PCR. Data were corrected using the GAPDH signal as an internal control and the results are expressed as a percentage of controls. Each value is the mean $( \pm S E M)$ of at least four different wells from three independent experiments. ANOVA followed by the Bonferroni's test. ${ }^{*} p<0.05$;
${ }^{* *} p<0.01 ;{ }^{* * *} p<0.001$; NS, not statistically different vs. control. (B) Effects of ODN on $\mathrm{H}_{2} \mathrm{O}_{2}$-evoked inhibition of SOD and catalase mRNA levels. Cells were pre-incubated for $10 \mathrm{~min}$ in the absence or presence of $0.1 \mathrm{nM}$ ODN, and then incubated for $1 \mathrm{~h}$ with medium alone or with graded concentrations of $\mathrm{H}_{2} \mathrm{O}_{2}(100-500 \mu \mathrm{M})$ in the absence or presence of ODN. The results are expressed as a percentage of control. Each value is the mean $( \pm S E M)$ of at least four different wells from three independent experiments. Analyses similar to those in (A) were performed and symbols show the significance vs. $\mathrm{H}_{2} \mathrm{O}_{2}$-treated cells: ${ }^{\#} p<0.05$; ${ }^{\# \#} p<0.01$; ${ }^{\# \#} p<0.001$; ns, not statistically different. 
A

\section{SOD}
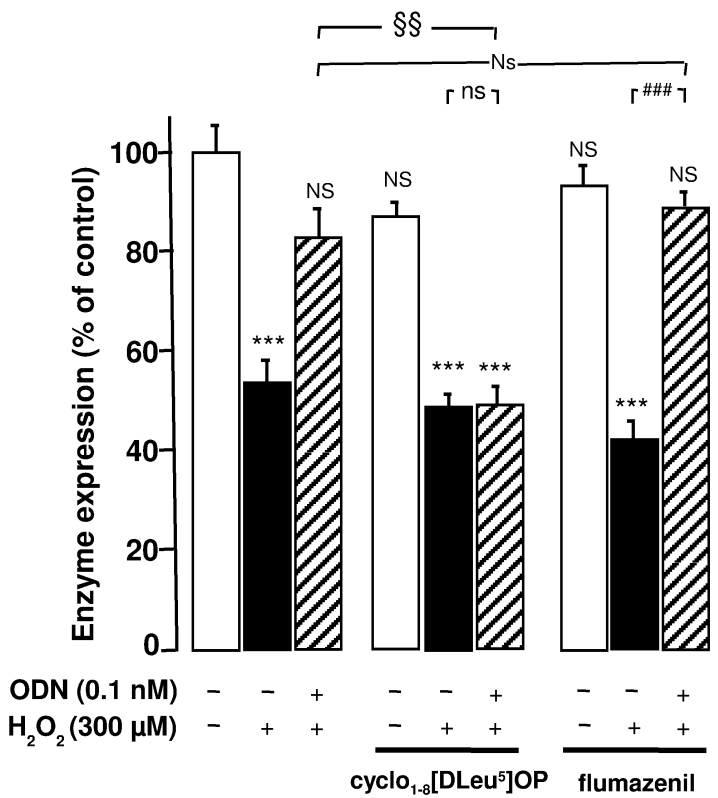

B SOD

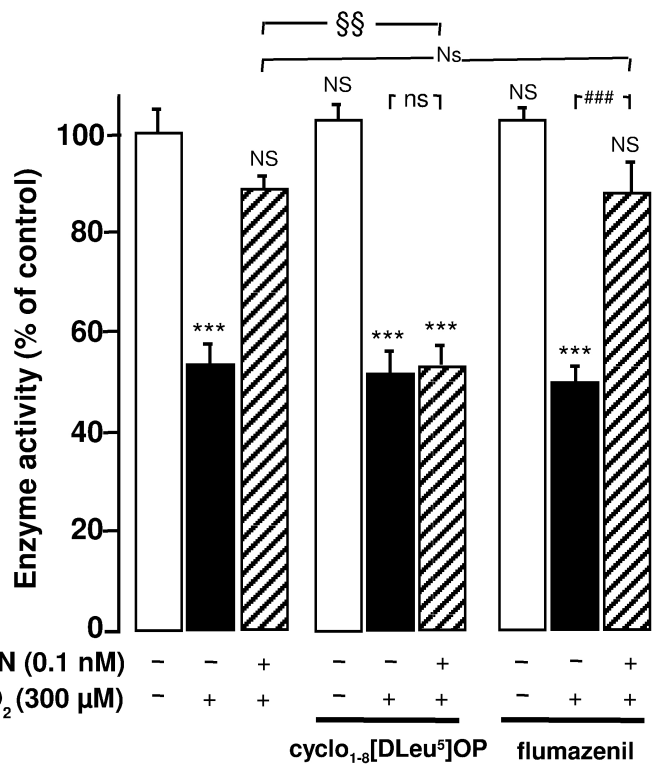

Catalase
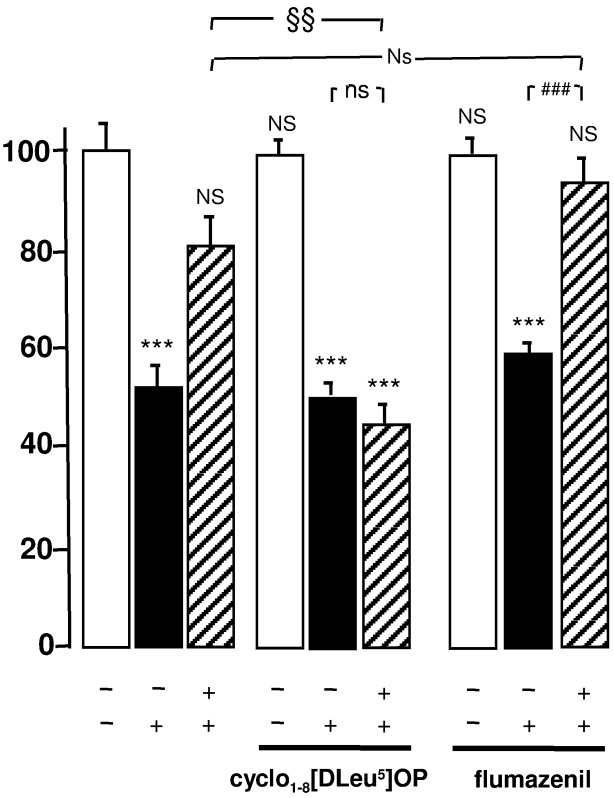

\section{Catalase}

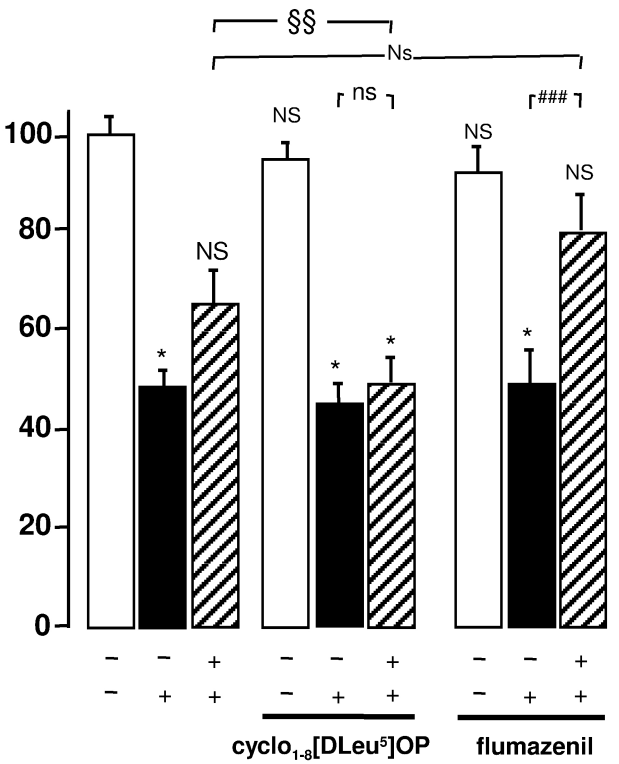

FIGURE 2 | Involvement of the G protein-coupled receptor of ODN in its protective effects against the deleterious action of $\mathrm{H}_{2} \mathrm{O}_{2}$ on SOD and catalase in cultured rat astrocytes. Astrocytes were pre-incubated for $30 \mathrm{~min}$ in the absence or presence of the metabotropic receptor antagonist $\mathrm{cyclo}_{1-8}\left[\mathrm{Dleu}^{5}\right] \mathrm{OP}(1 \mu \mathrm{M})$ or the CBR antagonist flumazenil $(1 \mu \mathrm{M})$ and then incubated for $1 \mathrm{~h}$ with medium alone or with $300 \mu \mathrm{M} \mathrm{H}_{2} \mathrm{O}_{2}$ without or with ODN (0.1 nM). (A) SOD and catalase mRNA levels were quantified as described in Figure 1. The results are expressed as a percentage of control. Each value is the mean $( \pm S E M)$ of at least three different wells from three independent experiments. (B) The activity of SOD was measured using a spectrophotometric assay which consists in measuring epinephrine autoxidation induced by superoxide anion, and catalase activity was determined on the basis of the decomposition of $\mathrm{H}_{2} \mathrm{O}_{2}$. The results are expressed as a percentage of SOD or catalase activity with respect to control. Each value is the mean ( $(\mathrm{SEM})$ of at least four different dishes from three independent experiments. ANOVA followed by the Bonferroni's test: [(A, SOD) $F=7.69, d f=40$; (A, catalase) $F=8.58$, $d f=39$; (B, SOD) $F=13.41, d f=44 ;(\mathbf{B}$, catalase) $F=7.58, d f=44]$; ${ }^{*} p<0.05$; ${ }^{* *} p<0.001$; NS, not statistically different vs. control. $\# \#$ $p<0.001 ; n s$, not statistically different vs. $\mathrm{H}_{2} \mathrm{O}_{2}$-treated cells. Two-way ANOVA test: [(A, SOD) $F=5, d f=17$; (A, catalase) $F=8.13, d f=17$; (B, SOD) $F=5.87, d f=20$; (B, catalase) $F=2.79, d f=19] ;{ }^{\S} p<0.05$; $\S \S p<0.01$; Ns, not statistically different vs. ODN $+\mathrm{H}_{2} \mathrm{O}_{2}$-cotreated cells. 
A

$S O D$

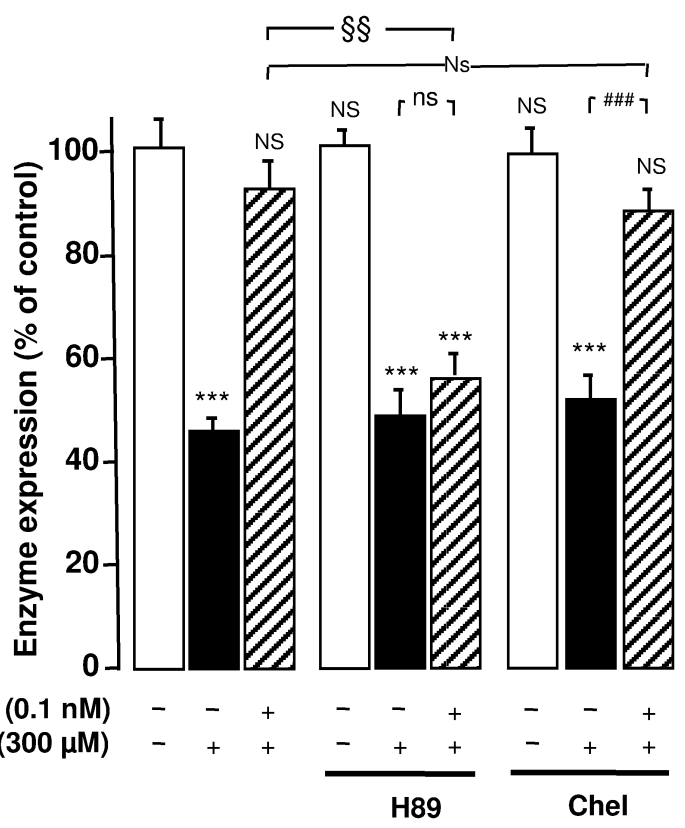

B

$S O D$

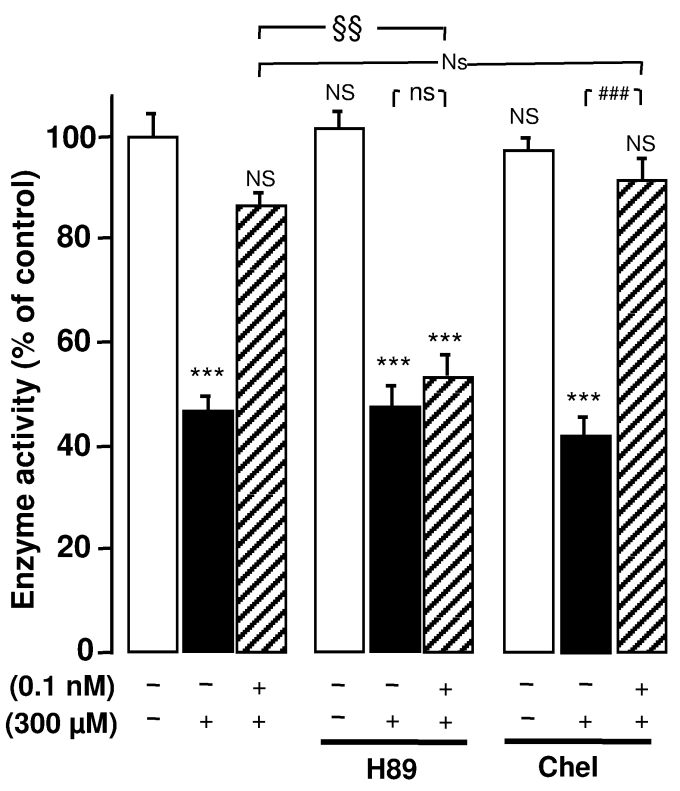

Catalase

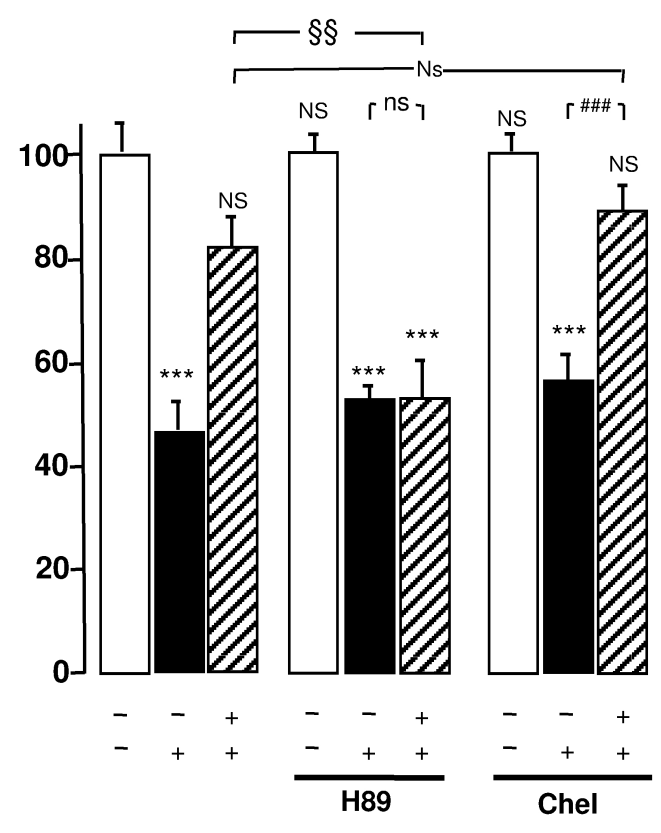

Catalase

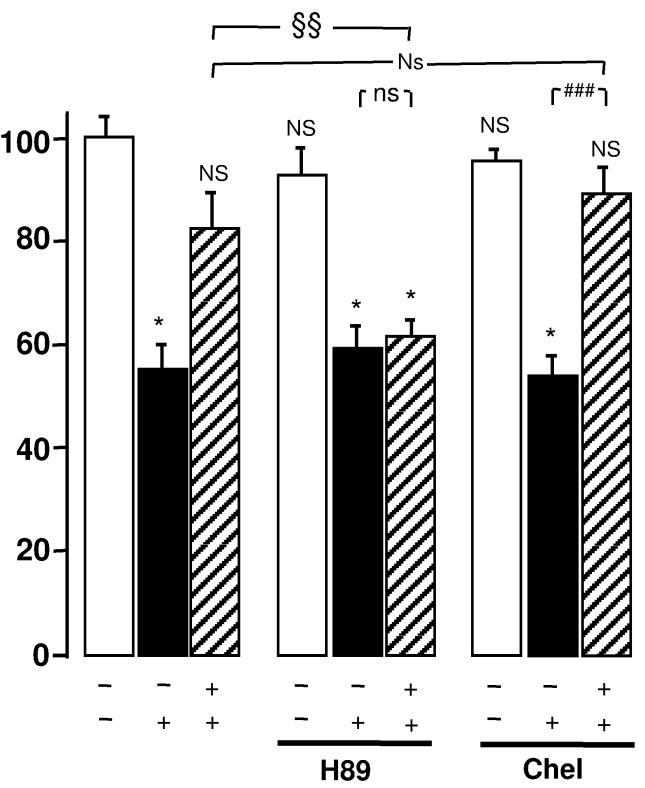

FIGURE 3 | Protein kinase A-dependence of the protective effects of ODN on the expression and activities of SOD and catalase in cultured rat astrocytes. Astrocytes were pre-treated for $30 \mathrm{~min}$ in the absence or presence of the PKA inhibitor H89 $(20 \mu \mathrm{M})$ or the PKC inhibitor chelerythrine (Chel; $0.1 \mu \mathrm{M}$ ) and then incubated for $1 \mathrm{~h}$ with medium alone or with $300 \mu \mathrm{M}$ $\mathrm{H}_{2} \mathrm{O}_{2}$ without or with ODN (0.1 nM). (A) SOD and catalase mRNA levels were quantified as described in Figure 1. The results are expressed as a percentage of controls. Each value is the mean $( \pm S E M)$ of at least three different wells from three independent experiments. (B) The activity of SOD and catalase were quantified as described in Figure 2. The results are expressed as a percentage of SOD or catalase activity with respect to control. Each value is the mean $( \pm S E M)$ of at least four different dishes from three independent experiments. ANOVA followed by the Bonferroni's test: $[(\mathbf{A}$, SOD) $F=7.49, d f=65 ;(\mathbf{A}$, catalase) $F=5.08, d f=53 ;(\mathbf{B}$, SOD) $F=12.37, d f=55$; $(\mathbf{B}$, catalase) $F=9.06, d f=60]$; ${ }^{*} p<0.05 ;{ }^{*}{ }^{*} p<0.001$; NS, not statistically different vs. control. \#\#\# $p<0.001$; ns, not statistically different vs. $\mathrm{H}_{2} \mathrm{O}_{2}$-treated cells. Two-way ANOVA test: [(A, SOD) $F=2.40$, $d f=20 ;(\mathbf{A}$, catalase) $F=2.63, d f=17 ;(\mathbf{B}, \mathrm{SOD}) F=6.97, d f=18$; $(\mathbf{B}$, catalase) $F=4.68, d f=24] ;{ }^{\S} p<0.05 ;{ }^{\S} p<0.01$; Ns, not statistically different vs. ODN $+\mathrm{H}_{2} \mathrm{O}_{2}$-cotreated cells. 
ODN-induced rapid activation of antioxidant systems is required for the long-lasting inhibition of the deleterious effect of $\mathrm{H}_{2} \mathrm{O}_{2}$. That ODN-induced increase of transcription and activity of antioxidant enzymes is responsible, at least in part, for inhibition of cell death is consistent with previous data showing that SOD and catalase blockers suppress the protective effect of ODN against $\mathrm{H}_{2} \mathrm{O}_{2}$-induced astrocyte apoptosis (Hamdi et al., 2011). Furthermore, it has been reported that, in cultured astrocytes, overexpression of SOD is able to prevent ROS-induced alteration of mitochondrial integrity, caspase- 3 activation and thus cells apoptosis (Yang et al., 2008).

Previous studies have shown that, in cultured astrocytes, ODN can interact with either CBR associated with the $\mathrm{GABA}_{\mathrm{A}}$ receptor (Gandolfo et al., 1999) or with a G protein-coupled receptor positively coupled to PLC (Patte et al., 1995; Leprince et al., 2001). Here, we found that the inhibitory effects of ODN on $\mathrm{H}_{2} \mathrm{O}_{2}$ evoked reduction of SOD and catalase mRNA levels and activities were suppressed by the ODN analog cyclo $_{1-8}\left[\mathrm{DLeu}^{5}\right] \mathrm{OP}$ but were not affected by the specific CBR antagonist flumazenil. It has been reported that the cyclic analog of ODN exerts potent antagonistic activities on ODN-induced polyphosphoinositide turnover increase and intracellular calcium mobilization in rat astrocytes (Leprince et al., 2001). Thus, these data indicate that the antioxidant action of ODN is mediated through the activation of the G protein-coupled receptor.

We next investigated the signaling cascade involved in the effect of ODN on endogenous antioxidant systems. ODN blockage of $\mathrm{H}_{2} \mathrm{O}_{2}$-evoked inhibition of SOD and catalase gene transcription and enzyme activities was totally abrogated by the PKA inhibitor H89, while the PKC inhibitor chelerythrine had no effect. That, the ODN G protein-coupled receptor could stimulate the AC/PKA transduction cascade is in agreement with recent data indicating that ODN increases the production of cAMP in astrocytes (Hamdi et al., 2012). Altogether, these observations indicate that the antioxidant action of ODN against $\mathrm{H}_{2} \mathrm{O}_{2}$-induced oxidative stress can be specifically ascribed to the activation of the AC/PKA signaling pathway. Consistent with this notion, it has been shown that the SOD and catalase promoters contain a CAMPresponsive element-like sequence (Das et al., 1995; Zelko et al., 2002; Colombo and Moncada, 2009) and that siRNA knockdown of cAMP-responsive element-binding protein (CREB) or inhibition of CREB phosphorylation blocks the expression of SOD in the rat hypothalamus (Hsieh et al., 2008) and the expression of catalase in human vascular endothelial cells (Colombo and Moncada, 2009), respectively. The fact that ODN provokes ERK phosphorylation via a cAMP-dependent pathway in astrocytes (Hamdi et al., 2012), strongly suggests that the stimulatory

\section{REFERENCES}

Alfonso, J., Le Magueresse, C., Zuccotti, A., Khodosevich, K., and Monyer, $\mathrm{H}$. (2012). Diazepam binding inhibitor promotes progenitor proliferation in the postnatal SVZ by reducing GABA signaling. Cell Stem Cell 10, 76-87.

Bi, J., Jiang, B., Liu, J. H., Lei, C., Zhang, X. L., and An, L. J. (2008). Protective effects of catalpol against
$\mathrm{H}_{2} \mathrm{O}_{2}$-induced oxidative stress in astrocytes primary cultures. Neurosci. Lett. 442, 224-227.

Burgi, B., Lichtensteiger, W., Lauber, M. E., and Schlumpf, M. (1999). Ontogeny of diazepam binding inhibitor/acyl-CoA binding protein mRNA and peripheral benzodiazepine receptor mRNA expression in the rat. $\mathrm{J}$. Neuroendocrinol. 11, 85-100. effect of ODN on SOD and catalase expression can also be ascribed to activation of the ERK-type MAP kinase transduction pathway.

The protective effect of ODN against $\mathrm{H}_{2} \mathrm{O}_{2}$-reduced antioxidant enzyme expression and activities might have a physiopathological significance in neurodegenerative diseases and stroke. CNS is sensitive to oxidative stress due to its high metabolic rate and high levels of unsaturated lipids so that up-regulation of antioxidant enzyme systems in astroglial cells could be beneficial against cell death observed during and after ischemia and neurodegenerative diseases. In agreement with this hypothesis, we have recently shown that the endozepine ODN exerts a potent protective action against apoptosis induced by oxidative stress in astrocytes (Hamdi et al., 2011, 2012) and that the anti-apoptotic effect of ODN is attributable to activation of the antioxidant enzymes that act as scavengers of $\mathrm{H}_{2} \mathrm{O}_{2}$ and ROS (Hamdi et al., 2011). The fact that the glioprotective action of ODN is likely mediated through the metabotropic receptor is of particular interest. Previous data indicate that ODN induces a wide range of activities through activation of CBR (Tonon et al., 2006). In particular, ODN has been initially described as an anxiogenic peptide (De Mateos-Verchere et al., 1998). Since cyclic analog of ODN do not recognize CBR (Leprince et al., 2001), the development of specific cyclic agonists that would selectively mimic the glioprotective effect of ODN might prove useful for the treatment of ischemia and neurodegenerative diseases.

In conclusion, the present study has demonstrated that the endozepine ODN, acting through a metabotropic receptor sensitive to the $\mathrm{cyclo}_{1-8}\left[\mathrm{DLeu}^{5}\right] \mathrm{OP}$ antagonist, exerts a potent antioxidant action against $\mathrm{H}_{2} \mathrm{O}_{2}$-induced oxidative stress in astrocytes. This antioxidant effect of ODN is attributable to activation of both gene expression and activities of enzymatic antioxidant systems and can be ascribed to the stimulation of the AC/PKA transduction pathway.

\section{ACKNOWLEDGMENTS}

Yosra Hamdi and Hadhemi Kaddour were recipients of fellowships from the University of Tunis El Manar and a France-Tunisia exchange program CMCU-Utique. Seyma Bahdoudi and Salma Douiri were recipients of fellowships from the University of Tunis El Manar and a France-Tunisia exchange program Inserm-DGRS. This study was supported by the Research Unit UR/11ES09, a CMCU-Utique program (to Mohamed Amri and Marie-Christine Tonon; grant number 07G0822), an Inserm-DGRS program (to Mohamed Amri and Marie-Christine Tonon; grant number $\mathrm{M}$ 10/M), Inserm (U982), the Institute for Medical Research and Innovation (IRIB) and the Région Haute-Normandie.
Castel, H., Diallo, M., Chatenet, D., Leprince, J., Desrues, L., Schouft, M. T., et al. (2006). Biochemical and functional characterization of highaffinity urotensin II receptors in rat cortical astrocytes. J. Neurochem. 99 , 582-595.

Chen, Y., Chan, P. H., and Swanson, R. A. (2001). Astrocytes overexpressing $\mathrm{Cu}, \mathrm{Zn}$ superoxide dismutase have increased resistance to oxidative injury. Glia 33, 343-347.

Colombo, S. L., and Moncada, S. (2009). $A M P K \alpha 1$ regulates the antioxidant status of vascular endothelial cells. Biochem. J. 421, 163-169.

Compère, V., Lanfray, D., Castel, H., Morin, F., Leprince, J., Dureuil, B., et al. (2010). Acute food deprivation reduces expression of 
diazepam-binding inhibitor, the precursor of the anorexigenic octadecaneuropeptide ODN, in mouse glial cells. J. Mol. Endocrinol. 44, 295-299.

Compère, V., Li, S., Leprince, J., Tonon, M. C., Vaudry, H., and Pelletier, G. (2003). Effect of intracerebroventricular administration of the octadecaneuropeptide on the expression of pro-opiomelanocortin, neuropeptide $\mathrm{Y}$ and corticotropin-releasing hormone mRNAs in rat hypothalamus. J. Neuroendocrinol. 15, 197-203.

Compère, V., Li, S., Leprince, J., Tonon, M. C., Vaudry, H., and Pelletier, G. (2004). In vivo action of a new octadecaneuropeptide (ODN) antagonist on gonadotropinreleasing hormone gene expression in the male rat brain. Neuroscience 125, 411-415.

Das, K. C., Lewis-Molock, Y., and White, C. W. (1995). Activation of $\mathrm{NF}-\kappa \mathrm{B}$ and elevation of MnSOD gene expression by thiol reducing agents in lung adenocarcinoma (A549) cells. Am. J. Physiol. 269, L588-L602.

De Mateos-Verchere, J. G., Leprince, J., Tonon, M. C., Vaudry, H., and Costentin, J. (1998). The octadecaneuropeptide ODN induces anxiety in rodents: possible involvement of a shorter biologically active fragment. Peptides 19, 841-848.

Desagher, S., Glowinski, J., and Premont, J. (1996). Astrocytes protect neurons from hydrogen peroxide toxicity. J. Neurosci. 16, 2553-2562.

Do Rego, J. L., Mensah-Nyagan, A. G., Beaujean, D., Leprince, J., Tonon, M. C., Luu-The, V., et al. (2001). The octadecaneuropeptide ODN stimulates neurosteroid biosynthesis through activation of central-type benzodiazepine receptors. J. Neurochem. 76, 128-138.

Do Rego, J. C., Orta, M. H., Leprince, J., Tonon, M. C., Vaudry, H., and Costentin, J. (2007). Pharmacological characterization of the receptor mediating the anorexigenic action of the octadecaneuropeptide: evidence for an endozepinergic tone regulating food intake. Neuropsychopharmacology 32, 1641-1648.

Dong, E., Matsumoto, K., Tohda, M., and Watanabe, H. (1999). Involvement of diazepam binding inhibitor and its fragment octadecaneuropeptide in social isolation stress-induced decrease in pentobarbital sleep in mice. Life Sci. 64, 1779-1784.

Dringen, R., Kussmaul, L., Gutterer, J. M., Hirrlinger, J., and Hamprecht, B. (1999). The glutathione system of peroxide detoxification is less efficient in neurons than in astroglial cells. J. Neurochem. 72, 2523-2530.
Emerit, J., Edeas, M., and Bricaire, F. (2004). Neurodegenerative diseases and oxidative stress. Biomed. Pharmacother. 58, 39-46.

Ferrero-Gutierrez, A., Perez-Gomez, A., Novelli, A., and Fernandez-Sanchez, M. T. (2008). Inhibition of protein phosphatases impairs the ability of astrocytes to detoxify hydrogen peroxide. Free Radic. Biol. Med. 44, 1806-1816.

Ferrero, P., Santi, M. R., ContiTronconi, B., Costa, E., and Guidotti, A. (1986). Study of an octadecaneuropeptide derived from diazepam binding inhibitor (DBI): biological activity and presence in rat brain. Proc. Natl. Acad. Sci. U.S.A. 83, 827-831.

Gandolfo, P., Patte, C., Thoumas, J. L. Leprince, J., Vaudry, H., and Tonon, M. C. (1999). The endozepine ODN stimulates $[3 \mathrm{H}]$ thymidine incorporation in cultured rat astrocytes. $\mathrm{Neu}$ ropharmacology 38, 725-732.

Garcia, A. G., Rodriguez-Rocha, H., Madayiputhiya, N., Pappa, A., Panayiotidis, M. I., and Franco, R. (2012). Biomarkers of protein oxidation in human disease. Curr. Mol. Med. 12, 681-697

Giffard, R. G., and Swanson, R A. (2005). Ischemia-induced programmed cell death in astrocytes. Glia 50, 299-306.

Guidotti, A., Forchetti, C. M., Corda, M. G., Konkel, D., Bennett, C. D., and Costa, E. (1983). Isolation, characterization, and purification to homogeneity of an endogenous polypeptide with agonistic action on benzodiazepine receptors. Proc. Natl. Acad. Sci. U.S.A. 80, 35313535.

Hamdi, Y., Kaddour, H., Vaudry, D., Bahdoudi, S., Douiri, S., Leprince, J., et al. (2012). The octadecaneuropeptide ODN protects astrocytes against hydrogen peroxide-induced apoptosis via a PKA/MAPK-dependent mechanism. PLoS ONE 7: e42498. doi: 10.1371/journal.pone.0042498.

Hamdi, Y., Masmoudi-Kouki, O., Kaddour, H., Belhadj, F., Gandolfo, P., Vaudry, D., et al. (2011). Protective effect of the octadecaneuropeptide on hydrogen peroxide-induced oxidative stress and cell death in cultured rat astrocytes. J. Neurochem. 118 , 416-428.

Hayashi, M., Miyata, R., and Tanuma, N. (2012). Oxidative stress in developmental brain disorders. Adv. Exp. Med. Biol. 724, 278-290.

Hsieh, Y. S., Yang, S. F., Chu, S. C., Ho, Y. J., Kuo, C. S., and Kuo, D. Y. (2008). Transcriptional interruption of cAMP response element binding protein modulates superoxide dismutase and neuropeptide Ymediated feeding behavior in freely moving rats. J. Neurochem. 105, 1438-1449.

Kavaliers, M., and Hirst, M. (1986). An octadecaneuropeptide (ODN) derived from diazepam binding inhibitor increases aggressive interactions in mice. Brain Res. 383, 343-349.

Kifle, Y., Monnier, J., Chesrown, S. E., Raizada, M. K., and Nick, H. S. (1996). Regulation of the manganese superoxide dismutase and inducible nitric oxide synthase gene in rat neuronal and glial cells. J. Neurochem. 66 , 2128-2135.

Leprince, J., Oulyadi, H., Vaudry, D., Masmoudi, O., Gandolfo, P., Patte, C., etal. (2001). Synthesis, conformational analysis and biological activity of cyclic analogs of the octadecaneuropeptide ODN. Design of a potent endozepine antagonist. Eur. J. Biochem. 268, 6045-6057.

Li, Y., Bao, Y., Jiang, B., Wang, Z., Liu, Y., Zhang, C., et al. (2008). Catalpol protects primary cultured astrocytes from in vitro ischemia-induced dam age. Int. J. Dev. Neurosci. 26, 309-317.

Lindenau, J., Noack, H., Possel, H., Asayama, K., and Wolf, G. (2000). Cellular distribution of superoxide dismutases in the rat CNS. Glia 29, 25-34.

Lopez, M. V., Cuadrado, M. P., RuizPoveda, O. M., Del Fresno, A. M. and Accame, M. E. (2007). Neuroprotective effect of individual ginsenosides on astrocytes primary culture. Biochim. Biophys. Acta 1770, 1308 1316.

Malagon, M., Vaudry, H., Van Strien, F., Pelletier, G., Gracia-Navarro, F. and Tonon, M. C. (1993). Ontogeny of diazepam-binding inhibitorrelated peptides (endozepines) in the rat brain. Neuroscience 57, 777-786.

Manabe, Y., Toyoda, T., Kuroda, K., Imaizum, M., Yamamoto, T., and Fushiki, T. (2001). Effect of diazepam binding inhibitor (DBI) on the fluid intake, preference and the taste reactivity in mice. Behav. Brain Res. 126, 197-204.

Mokuno, K., Ohtani, K., Suzumura, A., Kiyosawa, K., Hirose, Y., Kawai, K. et al. (1994). Induction of manganese superoxide dismutase by cytokines and lipopolysaccharide in cultured mouse astrocytes. J. Neurochem. 63 , 612-616.

Nenoi, M., Ichimura, S., Mita, K., Yukawa, O., and Cartwright, I. L. (2001). Regulation of the catalase gene promoter by Spl, CCAATrecognizing factors, and a WT1/Egrrelated factor in hydrogen peroxideresistant HP100 cells. Cancer Res. 61, 5885-5894.

Park, S. J., Kim, H. Y., Kim, H., Park, S. M., Joe, E. H., Jou, I., et al. (2009). Oxidative stress induces lipid-raft-mediated activation of Src homology 2 domain-containing protein-tyrosine phosphatase 2 in astrocytes. Free Radic. Biol. Med. 46, 1694-1702.

Patte, C., Vaudry, H., Desrues, L., Gandolfo, P., Strijdveen, I., Lamacz, M., et al. (1995). The endozepine ODN stimulates polyphosphoinositide metabolism in rat astrocytes. FEBS Lett. 362, 106-110.

Saha, R. N., and Pahan, K. (2007). Differential regulation of $\mathrm{Mn}$ superoxide dismutase in neurons and astroglia by HIV-1 gp120: implications for HIV-associated dementia. Free Radic. Biol. Med. 42, 1866-1878.

Shibata, N., and Kobayashi, M. (2008). The role for oxidative stress in neurodegenerative diseases. Brain Nerve 60, 157-170.

Sokolova, T., Gutterer, J. M., Hirrlinger, J., Hamprecht, B., and Dringen, R. (2001). Catalase in astrogliarich primary cultures from rat brain: immunocytochemical localization and inactivation during the disposal of hydrogen peroxide. $\mathrm{Neu}$ rosci. Lett. 297, 129-132.

Tokay, T., Hachem, R., MasmoudiKouki, O., Gandolfo, P., Desrues, L., Leprince, J., et al.(2008). Beta-amyloid peptide stimulates endozepine release in cultured rat astrocytes through activation of $N$ formyl peptide receptors. Glia 56, 1380-1389.

Tonon, M. C., Desy, L., Nicolas, P., Vaudry, H., and Pelletier, G. (1990). Immunocytochemical localization of the endogenous benzodiazepine ligand octadecaneuropeptide (ODN) in the rat brain. Neuropeptides 15, 17-24.

Tonon, M. C., Leprince, J., Gandolfo, P., Compère, V., Pelletier, G., Malagon, M. M., et al. (2006). "Endozepines" in Handbook of Biologically Active Peptides, ed. A. J. Kastin (New York: Elsevier), 813-819.

Vergara, D., Martignago, R., Bonsegna, S., De Nuccio, F., Santino, A., Nicolardi, G., et al. (2010). IFNbeta reverses the lipopolysaccharideinduced proteome modifications in treated astrocytes. J. Neuroimmunol. 221, 115-120.

Wang, J., Ma, J. H., and Giffard, R. G. (2005). Overexpression of copper/zinc superoxide dismutase 
decreases ischemia-like astrocyte injury. Free Radic. Biol. Med. 38, 1112-1118.

Yang, C. S., Tzou, B. C., Liu, Y. P., Tsai, M. J., Shyue, S. K., and Tzeng, S. F. (2008). Inhibition of cadmium-induced oxidative injury in rat primary astrocytes by the addition of antioxidants and the reduction of intracellular calcium. J. Cell. Biochem. 103, 825-834.

Zelko, I. N., Mariani, T. J., and Folz, R. J. (2002). Superoxide dismutase multigene family: a comparison of the CuZn-SOD (SOD1), Mn-SOD
(SOD2), and EC-SOD (SOD3) gene structures, evolution, and expression. Free Radic. Biol. Med. 33, 337-349.

Zhu, C. H., Huang, Y., Oberley, L. W., and Domann, F. E. (2001). A family of AP-2 proteins downregulate manganese superoxide dismutase expression. J. Biol. Chem. 276, 14407-14413.

Conflict of Interest Statement: The authors declare that the research was conducted in the absence of any commercial or financial relationships that could be construed as a potential conflict of interest.

Received: 05 September 2012; accepted: 26 October 2012; published online: 21 November 2012.

Citation: Hamdi Y, Kaddour H, Vaudry D, Douiri S, Bahdoudi S, Leprince J, Castel H, Vaudry H, Amri M, Tonon $M-C$ and Masmoudi-Kouki O (2012) The stimulatory effect of the octadecaneuropeptide ODN on astroglial antioxidant enzyme systems is mediated through a GPCR. Front. Endocrin. 3:138. doi: 10.3389/fendo.2012.00138
This article was submitted to Frontiers in Neuroendocrine Science, a specialty of Frontiers in Endocrinology.

Copyright (c) 2012 Hamdi, Kaddour, Vaudry, Douiri, Bahdoudi, Leprince, Castel, Vaudry, Amri, Tonon and Masmoudi-Kouki. This is an openaccess article distributed under the terms of the Creative Commons Attribution License, which permits use, distribution and reproduction in other forums, provided the original authors and source are credited and subject to any copyright notices concerning any third-party graphics etc. 